\title{
EDC IMPACT: Chemical UV filters can affect human sperm function in a progesterone-like manner
}

\author{
A Rehfeld 1,2,3, D L Egeberg 1,3, K Almstrup 1,3, J H Petersen ${ }^{1,3,4}$, S Dissing ${ }^{2}$ and N E Skakkebæk ${ }^{1,3}$ \\ ${ }^{1}$ Department of Growth and Reproduction, Copenhagen University Hospital, Rigshospitalet, Denmark \\ ${ }^{2}$ Department of Cellular and Molecular Medicine, Faculty of Health Sciences, University of Copenhagen, Copenhagen, Denmark \\ International Center for Research and Research Training in Endocrine Disruption of Male Reproduction and Child Health (EDMaRC), University of \\ Copenhagen, Rigshospitalet, Denmark \\ ${ }^{4}$ Department of Biostatistics, University of Copenhagen, Copenhagen, Denmark \\ Correspondence should be addressed to N E Skakkebæk: nes@rh.dk
}

This paper forms part of a special series on the effect of endocrine disrupting chemicals (EDCs) on development and male reproduction. This paper is based on work presented at the 9th Copenhagen Workshop on Endocrine Disrupters, 2-5 May 2017, Copenhagen, Denmark

\begin{abstract}
Human sperm cell function must be precisely regulated to achieve natural fertilization. Progesterone released by the cumulus cells surrounding the egg induces a $\mathrm{Ca}^{2+}$ influx into human sperm cells via the CatSper $\mathrm{Ca}^{2+}$-channel and thereby controls sperm function. Multiple chemical UV filters have been shown to induce a $\mathrm{Ca}^{2+}$ influx through CatSper, thus mimicking the effect of progesterone on $\mathrm{Ca}^{2+}$ signaling. We hypothesized that these UV filters could also mimic the effect of progesterone on sperm function. We examined 29 UV filters allowed in sunscreens in the US and/or EU for their ability to affect acrosome reaction, penetration, hyperactivation and viability in human sperm cells. We found that, similar to progesterone, the UV filters 4-MBC, 3-BC, Meradimate, Octisalate, BCSA, HMS and OD-PABA induced acrosome reaction and 3-BC increased sperm penetration into a viscous medium. The capacity of the UV filters to induce acrosome reaction and increase sperm penetration was positively associated with the ability of the UV filters to induce a $\mathrm{Ca}^{2+}$ influx. None of the UV filters induced significant changes in the proportion of hyperactivated cells. In conclusion, chemical UV filters that mimic the effect of progesterone on $\mathrm{Ca}^{2+}$ signaling in human sperm cells can similarly mimic the effect of progesterone on acrosome reaction and sperm penetration. Human exposure to these chemical UV filters may impair fertility by interfering with sperm function, e.g. through induction of premature acrosome reaction. Further studies are needed to confirm the results in vivo.
\end{abstract}

\section{Key Words}

- endocrine disrupting chemicals

- UV filters

- fertility

- CatSper

- progesterone

human sperm
Endocrine Connections (2018) 7, 16-25

\section{Introduction}

Human male infertility is a common problem worldwide (1). The causes are in many cases unknown, but exposure to endocrine disrupting chemicals (EDCs) has been suspected to be involved $(2,3)$. Sperm cell dysfunction is a common cause of infertility (4) and intra-cytoplasmic sperm injection (ICSI), a method developed to treat male infertility due to sperm dysfunction, is increasingly used in both the United States (5) and in Europe (6). The reasons for the increasing use of ICSI are unknown, but it has been hypothesized that environmental factors may play a role (1). 
Sperm function must be precisely controlled, during the journey of the sperm cells through the female reproductive tract, for natural fertilization to occur $(7,8)$. Many sperm functions are controlled via the intracellular $\mathrm{Ca}^{2+}$ concentration $\left(\left[\mathrm{Ca}^{2+}\right]_{\mathrm{i}}\right)$, including sperm motility, chemotaxis and acrosome reaction (7). To be able to fertilize the egg, these individual $\left[\mathrm{Ca}^{2+}\right]_{\mathrm{i}}$-controlled sperm functions must be triggered at the correct time and in the correct order (7). CatSper (cationic channel of sperm) channels, located in the plasma membrane of the human sperm cell flagellum, are the principal facilitators of channel-mediated $\mathrm{Ca}^{2+}$ influx (9). CatSper is activated by the natural ligands progesterone and prostaglandins $(10,11)$, which lead to a rapid $\mathrm{Ca}^{2+}$ influx into the sperm cell. The cumulus cells surrounding the egg release progesterone and the progesterone-induced $\mathrm{Ca}^{2+}$ influx has been shown to mediate chemotaxis toward the egg $(8,12)$, to control sperm motility $(13,14)$ and to induce acrosome reaction (15).

CatSper can be promiscuously activated by various ligands (16), including multiple EDCs $(17,18,19,20$, 21). Our recent study examined 29 of the 31 chemical UV filters allowed in sunscreens in the EU and/or US for their ability to induce a rise in $\left[\mathrm{Ca}^{2+}\right]_{\mathrm{i}}$ in human sperm cells and showed that 13 chemical UV filters induced a rise in $\left[\mathrm{Ca}^{2+}\right]_{\mathrm{i}}$ in human sperm cells (21). Nine of these seemed to induce a $\mathrm{Ca}^{2+}$ influx through interaction with CatSper, thereby mimicking the effect of progesterone. As the progesterone-induced $\mathrm{Ca}^{2+}$ influx controls important sperm cell functions, including sperm motility and acrosome reaction, we here examined the chemical UV filters for their ability to interfere with the human sperm cell functions acrosome reaction, sperm penetration into a viscous medium and hyperactivation, as well as with sperm viability.

\section{Materials and methods}

\section{Reagents and chemical UV filters}

We were able to obtain 30 , out of the 31 chemical UV filters allowed in sunscreens in the EU and/or US (Table 1) from various chemical providers and to dissolve 29 of these in DMSO or ethanol as previously described (21). Progesterone, ionomycin, fluorescein isothiocyanateconjugated Pisum sativum agglutinin (FITC-PSA) and $4000 \mathrm{cP}$ methylcellulose were obtained from SigmaAldrich. Human serum albumin (HSA) was obtained from Irvine Scientific (CA, USA). Propidium iodide (PI),

$$
\text { http://www.endocrineconnections.org }
$$

Hoechst-33342 (Hoechst) and S100 were obtained from ChemoMetec A/S (Allerød, Denmark).

\section{Semen samples}

All semen samples were produced by masturbation and ejaculated into clean, wide-mouthed plastic containers, on the same day as the experiment. After ejaculation, the samples were allowed to liquefy for $15-30 \mathrm{~min}$ at $37^{\circ} \mathrm{C}$.

\section{Purification of motile sperm cells via swim-up}

Motile spermatozoa were recovered from raw ejaculates by swim-up separation in human tubular fluid $\left(\mathrm{HTF}^{+}\right)$ medium containing: $97.8 \mathrm{mM} \mathrm{NaCl}, 4.69 \mathrm{mM} \mathrm{KCl}, 0.2 \mathrm{mM}$ $\mathrm{MgSO}_{4}, \quad 0.37 \mathrm{mM} \quad \mathrm{KH}_{2} \mathrm{PO}_{4}, \quad 2.04 \mathrm{mM} \quad \mathrm{CaCl}_{2}, \quad 0.33 \mathrm{mM}$ Na-pyruvate, $21.4 \mathrm{mM}$ Na-lactate, $2.78 \mathrm{mM}$ glucose, $21 \mathrm{mM}$ HEPES, and $4 \mathrm{mM} \mathrm{NaHCO}_{3}$, adjusted to $\mathrm{pH} 7.3-7.4$ with $\mathrm{NaOH}$ as described elsewhere (17). After $1 \mathrm{~h}$ at $37^{\circ} \mathrm{C}$, the swim-up fraction was removed carefully and sperm concentration was determined by image cytometry as described in $(22,23)$. After two washes, the sperm samples were adjusted to $10 \times 10^{6} / \mathrm{mL}$ in $\mathrm{HTF}^{+}$with $\mathrm{HSA}(3 \mathrm{mg} / \mathrm{mL})$ and the sperm cells were incubated for at least $1 \mathrm{~h}$ at $37^{\circ} \mathrm{C}$.

For the experiments with capacitated sperm cells, the semen samples were instead adjusted to $10 \times 10^{6} / \mathrm{mL}$ (for acrosome reaction experiments) or $20 \times 10^{6} / \mathrm{mL}$ (for hyperactivation experiments) in a capacitating medium containing: $72.8 \mathrm{mM} \mathrm{NaCl}, 4.69 \mathrm{mM} \mathrm{KCl}, 0.2 \mathrm{mM} \mathrm{MgSO}_{4}$, $0.37 \mathrm{mM} \mathrm{KH}_{2} \mathrm{PO}_{4}, 2.04 \mathrm{mM} \mathrm{CaCl}, 0.33 \mathrm{mM}$ Na-pyruvate, $21.4 \mathrm{mM}$ Na-lactate, $2.78 \mathrm{mM}$ glucose, $21 \mathrm{mM}$ HEPES, and $25 \mathrm{mM} \mathrm{NaHCO}$, adjusted to $\mathrm{pH}$ 7.3-7.4 with $\mathrm{NaOH}$. $3 \mathrm{mg} / \mathrm{mL}$ (for acrosome reaction experiments) or $10 \mathrm{mg} / \mathrm{mL}$ (for hyperactivation experiments) HSA was added to the capacitating medium and the sperm cells were incubated for at least $3 \mathrm{~h}$ at $37^{\circ} \mathrm{C}$ in a $10 \% \mathrm{CO}_{2}$ atmosphere as previously described (21). The higher HSA concentration for the hyperactivation experiments was used to minimize the sperm cells 'sticking-to-glass' phenomenon (24).

\section{Assessment of acrosome reaction}

FITC-PSA can be used to stain the acrosome of sperm cells undergoing acrosome reaction $(25,26)$. Zoppino et al. have used FITC-PSA in combination with PI to identify viable acrosome-reacted sperm cells using flow cytometry (26). Here, we employ a similar approach using an image cytometer. A suspension of capacitated sperm cells with a sperm cell concentration of $10 \times 10^{6} / \mathrm{mL}$ was divided into equal aliquots and mixed with a staining solution

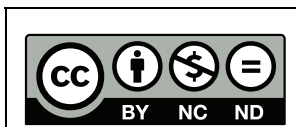

This work is licensed under a Creative Commons Attribution-NonCommercial-NoDerivatives 4.0 International License. 
Table 1 Chemical UV filters investigated. UV filters ranked according to their ability to induce $\mathrm{Ca}^{2+}$ signals $10 \mu \mathrm{M}(21)$.

\begin{tabular}{|c|c|c|c|c|c|c|}
\hline \multirow[b]{2}{*}{ Group } & \multirow[b]{2}{*}{ Rank } & \multirow[b]{2}{*}{ INCI name } & \multirow[b]{2}{*}{ CAS \# } & \multirow[b]{2}{*}{ Abbreviation } & \multicolumn{2}{|c|}{$\begin{array}{l}\text { Allowance in } \\
\text { sunscreens }\end{array}$} \\
\hline & & & & & EU (\%) & US $(\%)$ \\
\hline \multirow{13}{*}{$\begin{array}{l}\text { UV filters that induce } \\
\mathrm{Ca}^{2+} \text { signals at } 10 \mu \mathrm{M}\end{array}$} & 1 & 4-Methylbenzylidene camphor & $36861-47-9 / 38102-62-4$ & 4-MBC & 4 & \\
\hline & 2 & 3-Benzylidene camphor & $15087-24-8$ & $3-B C$ & 2 & \\
\hline & 3 & Menthyl anthranilate & 134-09-8 & Meradimate & & 5 \\
\hline & 4 & Isoamyl P-methoxycinnamate & 71617-10-2 & Amiloxate & 10 & \\
\hline & 5 & Ethylhexyl salicylate & $118-60-5$ & Octisalate & 5 & 5 \\
\hline & 6 & Benzylidene camphor sulfonic acid & $56039-58-8$ & BCSA & 6 & \\
\hline & 7 & Homosalate & 118-56-9 & HMS & 10 & 15 \\
\hline & 8 & Ethylhexyl dimethyl PABA & $21245-02-3$ & OD-PABA & 8 & 8 \\
\hline & 9 & Benzophenone-3 & 131-57-7 & BP-3 & 10 & 6 \\
\hline & 10 & Ethylhexyl methoxycinnamate & $5466-77-3$ & Octinoxate & 10 & 7.5 \\
\hline & 11 & Octocrylene & $6197-30-4$ & Octocrylene & 10 & 10 \\
\hline & 12 & Butyl methoxydibenzoylmethane & 70356-09-1 & Avobenzone & 5 & 3 \\
\hline & 13 & $\begin{array}{l}\text { Diethylamino hydroxybenzoyl } \\
\text { hexyl benzoate }\end{array}$ & $302776-68-7$ & DHHB & 10 & \\
\hline \multirow{16}{*}{$\begin{array}{l}\text { UV filters that do not } \\
\text { induce } \mathrm{Ca}^{2+} \text { signals } \\
\text { at } 10 \mu \mathrm{M}\end{array}$} & 14 & Benzophenone-8 & $131-53-3$ & Dioxybenzone & & 3 \\
\hline & 15 & $\begin{array}{l}\text { Camphor benzalkonium } \\
\text { methosulfate }\end{array}$ & $52793-97-2$ & CBM & 6 & \\
\hline & 16 & Polysilicone-15 & 207574-74-1 & Polysilicone-15 & 10 & \\
\hline & 17 & Drometrizole trisiloxane & $155633-54-8$ & $\begin{array}{l}\text { Drometrizole } \\
\text { trisolane }\end{array}$ & 15 & \\
\hline & 18 & Benzophenone-4 & $4065-45-6$ & BP-4 & 5 & 10 \\
\hline & 19 & Diethylhexyl butamido triazone & $154702-15-5$ & Iscotrizinol & 10 & \\
\hline & 20 & Ethylhexyl triazone & $88122-99-0$ & $\begin{array}{l}\text { Ethylhexyl } \\
\text { triazone }\end{array}$ & 5 & \\
\hline & 21 & Cinoxate & $104-28-9$ & Cinoxate & & 3 \\
\hline & 22 & PEG-25 PABA & $116242-27-4$ & PEG-25 PABA & 10 & \\
\hline & 23 & $\begin{array}{l}\text { Bis-ethylhexyloxyphenol } \\
\text { methoxyphenyl triazine }\end{array}$ & $187393-00-6$ & Bemotrizinol & 10 & \\
\hline & 24 & Tea-salicylate & $2174-16-5$ & TEA salicylate & & 12 \\
\hline & 25 & Phenylbenzimidazole sulfonic acid & 27503-81-7 & Ensulizole & 8 & 4 \\
\hline & 26 & PABA & $150-13-0$ & PABA & & 15 \\
\hline & 27 & $\begin{array}{l}\text { Disodium phenyl dibenzimidazole } \\
\text { tetrasulfonate }\end{array}$ & $180898-37-7$ & Bisdisulizole & 10 & \\
\hline & 28 & Benzophenone-5 & $6628-37-1$ & BP-5 & 5 & \\
\hline & 29 & $\begin{array}{l}\text { Terephthalylidene dicamphor } \\
\text { sulfonic acid }\end{array}$ & $92761-26-7 / 90457-82-2$ & Ecamsule & 10 & \\
\hline
\end{tabular}

Based on their ability to induce $\mathrm{Ca}^{2+}$ signals, the UV filters are categorized into 'UV filters that induce $\mathrm{Ca}^{2+}$ signals at $10 \mu \mathrm{M}$ ' and 'UV filters that do not induce $\mathrm{Ca}^{2+}$ signals at $10 \mu \mathrm{M}^{\prime}$. INCI name, CAS \#, abbreviation and allowance in sunscreens in the EU and US are also listed in the table.

containing $5 \mu \mathrm{g} / \mathrm{mL}$ FITC-PSA and $0.5 \mu \mathrm{g} / \mathrm{mL}$ PI in $\mathrm{HTF}^{+}$as in (26). $10 \mu \mathrm{g} / \mathrm{mL}$ Hoechst was also added to the staining solution (see explanation below). Chemical UV filters $(10 \mu \mathrm{M})$ were added to the aliquots of stained capacitated sperm cells. As positive controls, ionomycin $(2 \mu \mathrm{M})$ and progesterone $(10 \mu \mathrm{M})$ were added to separate aliquots. As a negative control, $0.2 \%$ DMSO was used, as this matched the DMSO concentration of ionomycin, which had the highest DSMO concentration of the treatments. After addition of chemical UV filters and controls, the samples were mixed and placed on a gentle mixing heating plate at $37^{\circ} \mathrm{C}$. After $30 \mathrm{~min}$ of incubation, the aliquots were

http://www.endocrineconnections.org https://doi.org/10.1530/EC-17-0156 Published by Bioscientifica Ltd thoroughly mixed by pipetting and a $50 \mu \mathrm{L}$ sample was drawn and mixed with $100 \mu \mathrm{L}$ of an immobilizing solution containing $0.6 \mathrm{M} \mathrm{NaHCO}_{3}$ and $0.37 \%(\mathrm{v} / \mathrm{v})$ formaldehyde in distilled water. This solution was mixed by pipetting and immediately loaded in an A2 slide (ChemoMetec A/S, Allerød, Denmark) and assessed in a NC-3000 image cytometer (ChemoMetec A/S). The following protocol was applied: 2-color flexicyte with Hoechst defining the sperm cells to be analyzed; Ex475-Em560/35: exposure time $3000 \mathrm{~ms}$, Ex530-Em675/75: exposure time $500 \mathrm{~ms}$, with a minimum of 5000 analyzed cells (positive for Hoechst). PI intensity as a function of FITC-PSA intensity was plotted 
on bi-exponential scales, and specific quadrant gates were used to distinguish four groups:

1. PI-positive and FITC-PSA-positive cells: Acrosomereacted nonviable sperm cells.

2. PI-negative and FITC-PSA positive cells: Acrosomereacted viable sperm cells.

3. PI-positive and FITC-PSA-negative cells: Acrosomeintact nonviable sperm cells.

4. PI-negative and FITC-PSA-negative cells: Acrosomeintact viable sperm cells.

Control for spectral overlap between PSA and PI and definition of quadrant gates were carried out by labeling the cells singly with each fluorophore (data not shown). The obtained compensation matrix was applied to all measurements. To account for differences in capacitation between donors, only experiments with an induced positive increment of viable acrosome-reacted sperm cells for both positive controls compared to the negative control were included in the analysis.

\section{Assessment of sperm penetration into a viscous medium}

Sperm penetration tests with $4000 \mathrm{cP}$ methylcellulose $(1 \% \mathrm{w} / \mathrm{v})$ as an artificial viscous medium were used as in (14). The methylcellulose $(1 \% \mathrm{w} / \mathrm{v})$ was prepared in $\mathrm{HTF}^{+}$by adding $10 \mathrm{mg}$ methylcellulose per $\mathrm{mL}$ $\mathrm{HTF}^{+}$and mixing it by rotation overnight at RT. The methylcellulose $(1 \% \mathrm{w} / \mathrm{v})$ was introduced into glass capillary tubes (borosilicate microslides (VitroTubes) $0.20 \mathrm{~mm} \times 2.0 \mathrm{~mm} \times 10 \mathrm{~cm}$ (VitroCom, Mountain Lakes, NJ, USA)) by capillary forces, by placing the glass tubes vertically in a $1.5 \mathrm{~mL}$ microfuge tube with $750 \mu \mathrm{L}$ methylcellulose $(1 \% \mathrm{w} / \mathrm{v})$ for $15 \mathrm{~min}$. Care was taken to prevent air bubbles from entering the glass tubes. One end of the glass tube was sealed with wax (Hounisens laboratorieudstyr A/S, Jystrup, Denmark) and the open end was placed in a semen reservoir of a Kremer sperm penetration meter (R.B.M. Lab., Rødovre, Denmark). Just prior to the insertion of the glass tubes, either chemical UV filters $(10 \mu \mathrm{M}), 5 \mu \mathrm{M}$ progesterone (positive control) or $0.1 \%$ DMSO (negative control) were added to a $200 \mu \mathrm{L}$ non-capacitated sperm sample $\left(10 \times 10^{6} / \mathrm{mL}\right.$ in $\left.\mathrm{HTF}^{+}\right)$ loaded into the semen reservoirs of the Kremer sperm penetration meter. The Kremer sperm penetration meter was tilted at a $45^{\circ}$ angle and sperm cells were allowed to migrate into the methylcellulose $(1 \% \mathrm{w} / \mathrm{v})$ for $60 \mathrm{~min}$ at $37^{\circ} \mathrm{C}$. The glass tube was then removed, wiped to remove residual sperm cells from the surface of the glass and examined using phase contrast optics on an Olympus BX45 microscope at a total magnification of $\times 200$ (Olympus). The number of sperm cells was counted at $1 \mathrm{~cm}$ distance from the base of the tube, with two fields in each of four planes counted. Throughout the study, all samples were analyzed by the same observer. Only experiments with a positive increment in cell density at $1 \mathrm{~cm}$ for the positive control compared to the negative control, with more than 50 sperm cells counted at $1 \mathrm{~cm}$ for the positive control, and with more than 10 cells counted for the negative control were used for the analysis.

Assessment of proportion of hyperactivated sperm cells with computer-assisted semen analysis (CASA)

A suspension of capacitated sperm cells with a sperm cell concentration of $20 \times 10^{6} / \mathrm{mL}$ and a HSA concentration of $10 \mathrm{mg} / \mathrm{mL}$ was divided into equal aliquots and kept at $37^{\circ} \mathrm{C}$. Just prior to acquisition of sperm motility data, either chemical UV filters $(10 \mu \mathrm{M})$, progesterone $(5 \mu \mathrm{M})$ or a negative control $(0.1 \%$ DMSO), which matched the DMSO concentration of the chemical UV filters, was added to an aliquot of sperm sample. After mixing, a $4 \mu \mathrm{L}$ sample was transferred to a $16 \mu \mathrm{m}$ deep chamber (2 chambers (CASA) slide (CellVision, Oslo, Norway)), preheated to $37^{\circ} \mathrm{C}$ and placed on the heated motorized stage $\left(37^{\circ} \mathrm{C}\right)$ of an Olympus BX41 microscope with a $20 \times$ phase contrast objective (Olympus). The microscope was connected to a computer running the Copenhagen Rigshospitalet Image House Sperm Motility Analysis System (CRISMAS), version 8.0.5919 CASA software. Sperm motility data were acquired just as the cells stopped drifting though the slide (took about $1 \mathrm{~min}$ ) and was commenced $<2$ min after addition of chemical UV filters and controls. Motility characteristics were obtained at $60 \mathrm{~Hz}$ through a Bassler camera acA640120um (Basler AG, Ahrensburg, Germany). At least 200 sperm cells were counted on randomly selected fields in each sample and each sample was assessed in duplicates. Hyperactivated cells were identified using standard criteria: VCL $\geq 150 \mu \mathrm{m} / \mathrm{s}$, linearity $\leq 50 \%$ and ALH $\geq 7 \mu \mathrm{m}$ (27). As some samples contained clumps of immotile cells, we calculated the percentage of hyperactivated cells out of the total concentration of motile cells for each sample and used the mean value of the duplicates for further analysis. 


\section{Assessment of sperm viability}

Concentration of dead sperm cells was determined by image cytometry as in $(22,23)$, but using phosphatebuffered saline instead of S100 to dilute the sperm sample before running the assay. In this way, only the nonviable cells in the sample are stained with PI and counted.

\section{Ethical approval}

Human semen samples were obtained from healthy volunteers with their prior consent. After delivery, the samples were fully anonymized. Each donor received a fee of 500 DKK (about 75 US dollars) per sample for their inconvenience. All samples were analyzed on the day of delivery and destroyed immediately after the laboratory experiments. Because of the full anonymization and the destruction of the samples immediately after the laboratory experiments, no ethical approval was needed for this work, according to the regional scientific ethical committee of the Capital Region of Denmark.

\section{Statistical analysis}

All data were analyzed using two-way analysis of variance (ANOVA). This properly takes into account and adjusts for the considerable variation between donors as well as between experiments. By including positive and negative controls, the effect of the chemical UV filters can be given relative to a known control. The data were transformed with the natural logarithm to avoid variance heterogeneity and to obtain approximate normality of model residuals.

To display all data from each experiment in a single figure, we normalized the data relative to the positive control (acrosome reaction and viability data) or negative control (sperm penetration and hyperactivation data). $P$ values were corrected for multiple comparison type I error inflation by Dunnett's method. To relate the ability of the chemical UV filter to induce a rise in $\left[\mathrm{Ca}^{2+}\right]_{\mathrm{i}}$ to the ability to induce acrosome reaction or increase sperm penetration, we used the ability of the chemical UV filter to induce a rise in $\left[\mathrm{Ca}^{2+}\right]_{\mathrm{i}}$ as a continuous covariate in the analysis. This results in a correct test for association between acrosome reaction or sperm penetration and the ability to induce a rise in $\left[\mathrm{Ca}^{2+}\right]_{i}$, while taking into account the considerable variation between donors as well as between experiments. Statistical analyses were performed using proc mixed in SAS, version 9.4 (SAS Institute Inc., Cary, NC, USA).

\section{Results}

\section{Effect on sperm acrosome reaction}

Using an image-cytometer-based assay similar to that in (26), we investigated 29 chemical UV filters allowed in sunscreens in the EU and/or US (Table 1), for their ability to induce acrosome reaction in capacitated human sperm cells after $30 \mathrm{~min}$ of incubation. The chemical UV filters were tested at $10 \mu \mathrm{M}(n=3-5)$, along with two positive controls $(10 \mu \mathrm{M}$ progesterone and $2 \mu \mathrm{M}$ ionomycin) and a negative control (0.2\% DMSO). A significant increase in viable acrosome-reacted sperm cells was found after treatment with the UV filters 4 -MBC (adjusted $P$ value $<0.0001$ ), 3-BC (adjusted $P$ value $<0.0001$ ), Meradimate (adjusted $P$ value $<0.0001$ ), HMS (adjusted $P$ value $<0.0001$ ), Octisalate (adjusted $P$-value $=0.0036$ ), BCSA (adjusted $P$ value $=0.0241$ ) and OD-PABA (adjusted $P$ value $=0.0425$ ). A similar significant increase in viable acrosome-reacted sperm cells was found after treatment with progesterone (adjusted $P$ value $<0.0001$ ). In order to display all data in a single figure, we calculated the percentage of viable acrosome-reacted sperm cells relative to the ionomycin-induced response from each individual experiment (Fig. 1). Additionally, we calculated the relationship between the ability of the UV filter at $10 \mu \mathrm{M}$ to induce a rise in $\left[\mathrm{Ca}^{2+}\right]_{\mathrm{i}}(21)$ and to induce acrosome reaction and found a significant positive association (adjusted $P$ value <0.0001) (Fig. 2).

\section{Effect on penetration into viscous medium}

Using sperm penetration tests with methylcellulose (1\% $\mathrm{w} / \mathrm{v})$ as in (14), we investigated the 29 chemical UV filters for their effect on sperm penetration into a viscous medium. The UV filters were tested at $10 \mu \mathrm{M}(n=3-6)$, along with a positive control $(5 \mu \mathrm{M}$ progesterone) and a negative control (0.1\% DMSO). The increment in cell density at $1 \mathrm{~cm}$ was significantly increased after treatment with the UV filter 3-BC (adjusted $P$ value $=0.0347$ ), similar to the increment observed after treatment with $5 \mu \mathrm{M}$ progesterone (adjusted $P$ value $=0.0001$ ). In order to display all data in a single figure, we calculated the induced increment in cell density (in \% of control) at $1 \mathrm{~cm}$ into the viscous medium (Fig. 3). Furthermore, we calculated the relationship between the ability of the UV filter at $10 \mu \mathrm{M}$ to induce a rise in $\left[\mathrm{Ca}^{2+}\right]_{\mathrm{i}}(21)$ and to increase sperm penetration into viscous mucous and found a significant positive association (adjusted $P$ value $<0.0001$ ) (Fig. 4).

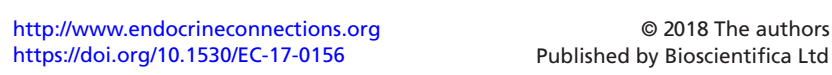




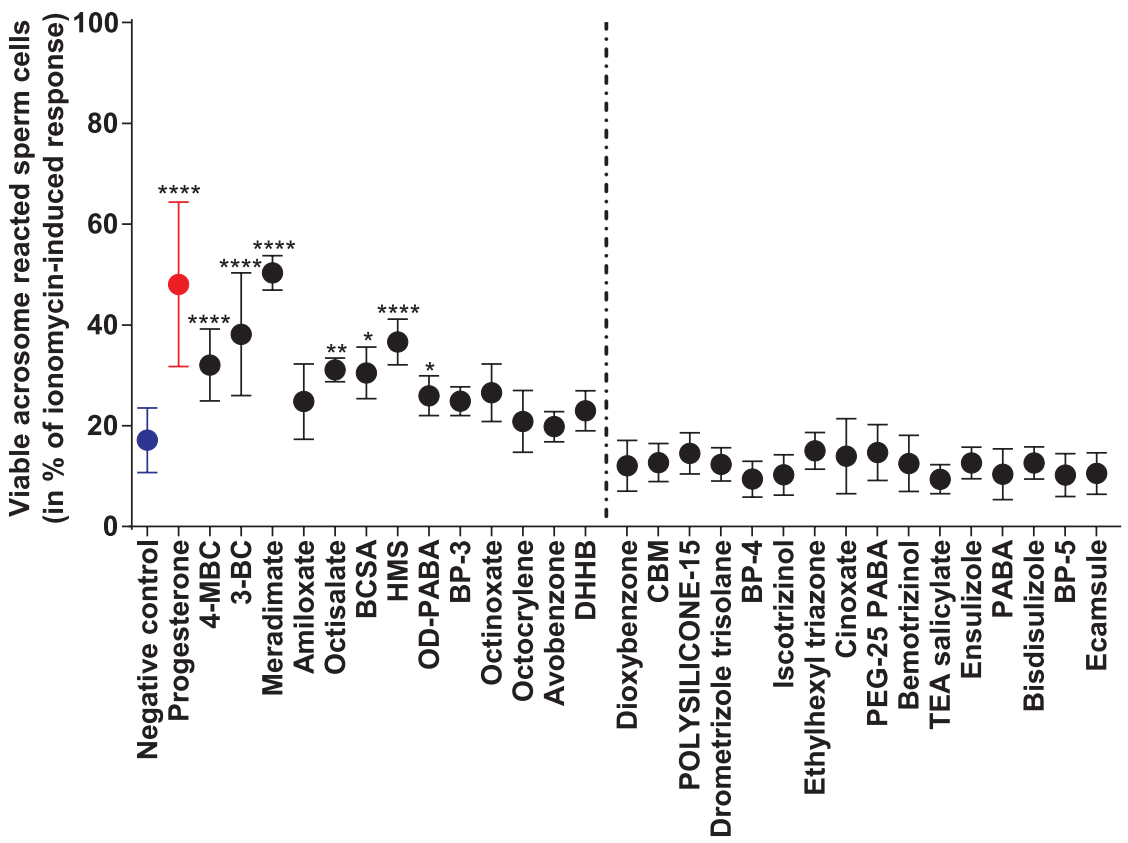

\begin{abstract}
Figure 1
Viable acrosome-reacted sperm cells (in \% of ionomycin-induced response) (mean \pm s.D.) after 30-min incubation with negative control $(0.2 \%$ DMSO), positive control (10 $\mu \mathrm{M}$ progesterone) and $10 \mu \mathrm{M}$ UV filters. The UV filters are ordered on the $x$-axis according to their ability to induce a rise in $\left[\mathrm{Ca}^{2+}\right]_{i}$, (decreasing from left to right). The UV filters left to the vertical line induce a rise in $\left[\mathrm{Ca}^{2+}\right]_{\mathrm{i}}$ at $10 \mu \mathrm{M}$, whereas those right of the vertical line do not induce a rise in $\left[\mathrm{Ca}^{2+}\right]_{i}$ at $10 \mu \mathrm{M}$ (21). ${ }^{* * * *}$ Adjusted $P$ value $\leq 0.0001$; ***adjusted $P$ value $\leq 0.001 ; * *$ adjusted $P$ value $\leq 0.01$ and *adjusted $P$ value $\leq 0.05$.
\end{abstract}

\section{Effect on hyperactivation}

Using computer-assisted semen analysis (CASA) we investigated the 29 chemical UV filters for effects on

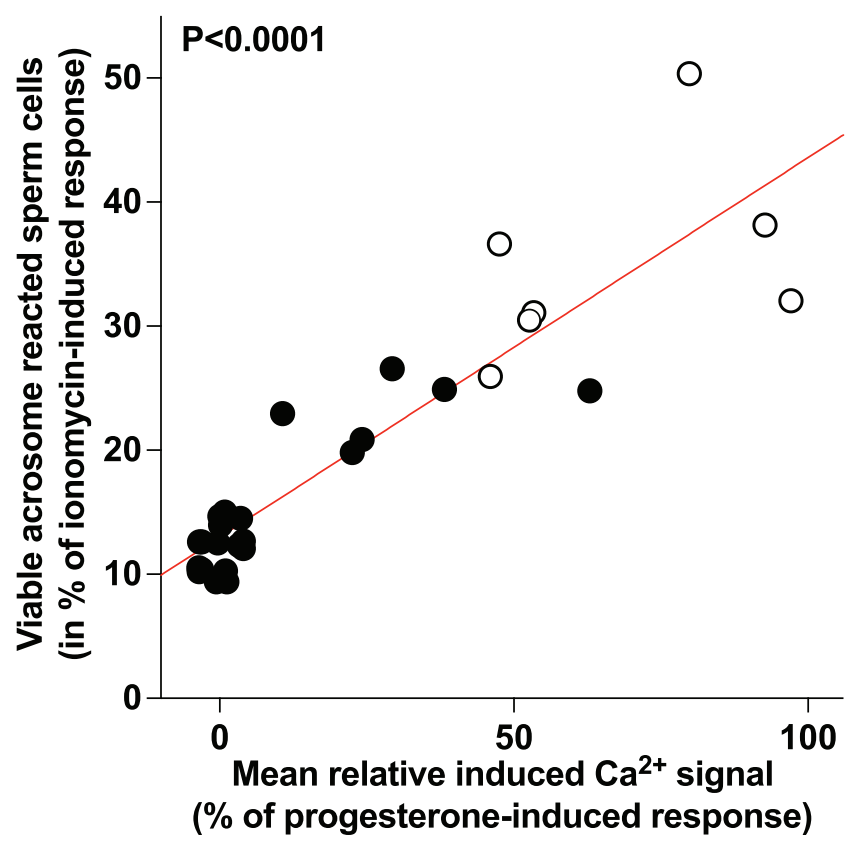

Figure 2

Scatter plot showing the ability of the chemical UV filter to induce a rise in $\left[\mathrm{Ca}^{2+}\right]_{i}$ at $10 \mu \mathrm{M}$ (in \% of the paired progesterone-induced response $(5 \mu \mathrm{M}))($ mean \pm S.D.) $(21)$ on the $x$-axis and the ability to induce acrosome reaction in viable sperm cells (in $\%$ of ionomycin-induces response) (mean \pm s.D.) on the $y$-axis. The white dots indicate UV filters that induced a significant increment in the amount of viable acrosome-reacted cells. The line is obtained by linear regression and the $P$ value for the association is obtained from the two-way ANOVA.

http://www.endocrineconnections.org https://doi.org/10.1530/EC-17-0156

(C) 2018 The authors Published by Bioscientifica Ltd hyperactivation in sperm cells. The UV filters were tested at $10 \mu \mathrm{M}(n=3-4)$, along with a positive control $(5 \mu \mathrm{M}$ progesterone) and a negative control (0.1\% DMSO). The percentage of hyperactivated sperm cells (in \% of total motile cells) was not significantly changed after treatment with any of the UV filters or with progesterone (adjusted $P$ values $>0.8732$ ). In order to display the data in a single figure, we calculated the induced increment in hyperactivation (in \% of control) (Supplementary Fig. 1, see section on supplementary data given at the end of this article).

\section{Effect on sperm viability}

Using an image-cytometer-based assay, we tested the 29 chemical UV filters for their effect on sperm viability. We incubated aliquots of non-capacitated sperm cells with the UV filters at $10 \mu \mathrm{M}$, along with a positive control $(0.5 \%$ Triton) and a negative control (0.1\% DMSO) for $20 \mathrm{~h}$ at $37^{\circ} \mathrm{C}$. Viability was found to be significantly decreased after treatment with the UV filter Avobenzone (adjusted $P$ value $=0.0051)$ (Fig. 5) .

\section{Discussion}

Here, we investigated the effects of 29 chemical UV filters on the human sperm cell functions acrosome reaction, sperm penetration into a viscous medium and hyperactivation, as well as on sperm viability. We found

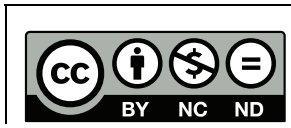

This work is licensed under a Creative Commons Attribution-NonCommercial-NoDerivatives 4.0 International License. 


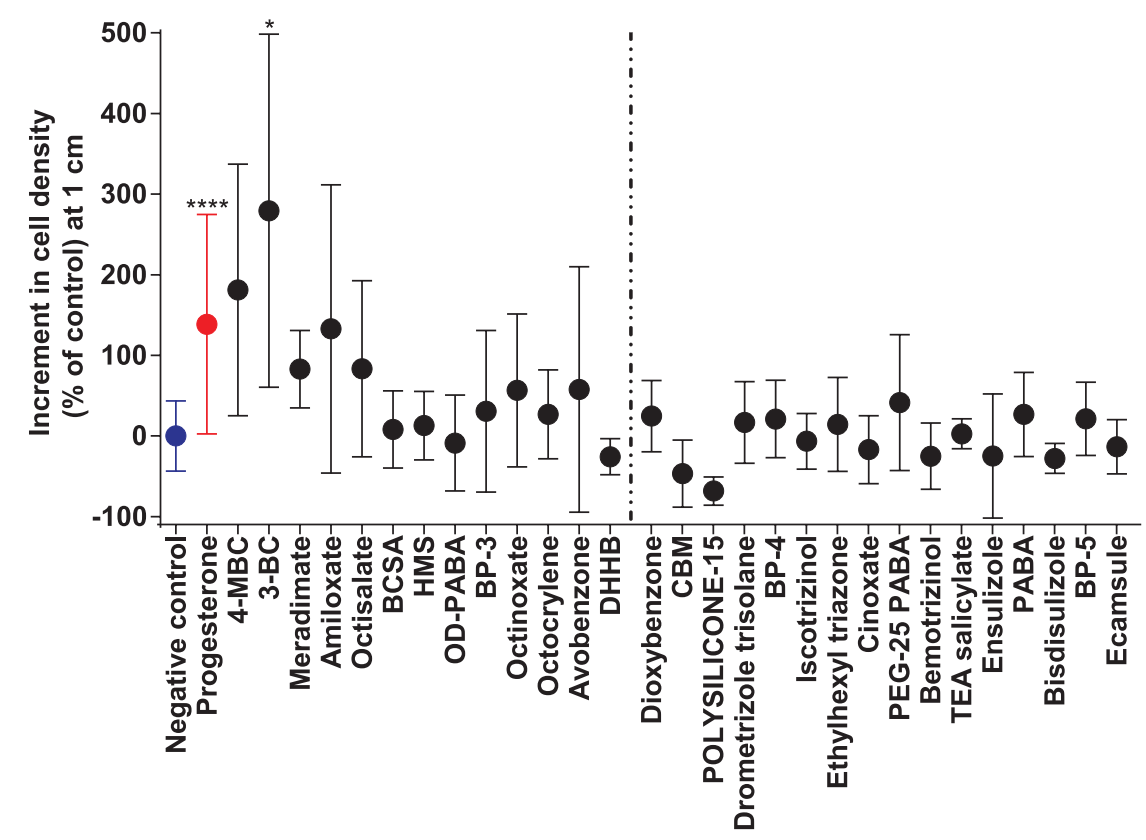

Figure 3

Increment in cell density at $1 \mathrm{~cm}$ into a viscous medium (in $\%$ of negative control) (mean \pm s.D.) after treatment of sperm cells with negative control (0.1\% DMSO), positive control ( $5 \mu \mathrm{M}$ progesterone) and $10 \mu \mathrm{M}$ UV filters $(n=3-6)$. The UV filters are ordered on the $x$-axis according to their ability to induce a rise in $\left[\mathrm{Ca}^{2+}\right]_{i}$, (decreasing from left to right). The UV filters left to the vertical line induce a rise in $\left[\mathrm{Ca}^{2+}\right]_{i}$ at $10 \mu \mathrm{M}$, whereas those right of the vertical line do not induce a rise in $\left[\mathrm{Ca}^{2+}\right]_{\mathrm{i}}$ at $10 \mu \mathrm{M}(21) . * * * *$ Adjusted $P$ value $\leq 0.0001$; *adjusted $P$ value $\leq 0.05$. that only chemical UV filters, which had previously been shown to induce a rise in $\left[\mathrm{Ca}^{2+}\right]_{i}$ in human sperm cells (21), affected sperm cell functions. Seven of these UV filters: 4-MBC, 3-BC, Meradimate, Octisalate, BCSA, HMS and OD-PABA were found to induce acrosome reaction, similar to the response induced by progesterone. In addition, we showed that the UV filter 3-BC increased sperm penetration into a viscous medium, similar to the response induced by progesterone. The ability of the UV filters to induce acrosome reaction and increase sperm penetration was found to be positively associated with the ability of the chemical UV filter to induce a rise in $\left[\mathrm{Ca}^{2+}\right]_{\mathrm{i}}$. None of the UV filters induced a change in the proportion of hyperactivated cells and viability was only decreased after treatment with the UV filter Avobenzone. None of the chemical UV filters that did not induce a rise in $\left[\mathrm{Ca}^{2+}\right]_{\mathrm{i}}$ in human sperm cells in our previous study (21) were found to affect sperm function.

Progesterone is a known inducer of acrosome reaction in human sperm cells (15) and a suboptimal induction of acrosome reaction in response to progesterone is associated with reduced male fertility $(28,29,30,31)$. An intact acrosome is required for mouse sperm cells to respond to progesterone-induced chemotaxis (32). Furthermore, only acrosome-intact human sperm cells can bind to the zona pellucida (33), in contrast to what has been found for mouse sperm cells $(34,35)$. Once bound to the zona pellucida, the human sperm cells must undergo acrosome reaction to penetrate the zona pellucida (36) and fuse with the egg (37). In line with this, a high level of spontaneous acrosome reaction has been associated

$$
\text { http://www.endocrineconnections.org }
$$

with reduced male fertility $(38,39,40)$, although the relationship was not found in two other studies $(31,41)$. This suggests that exposure to chemical UV filters could

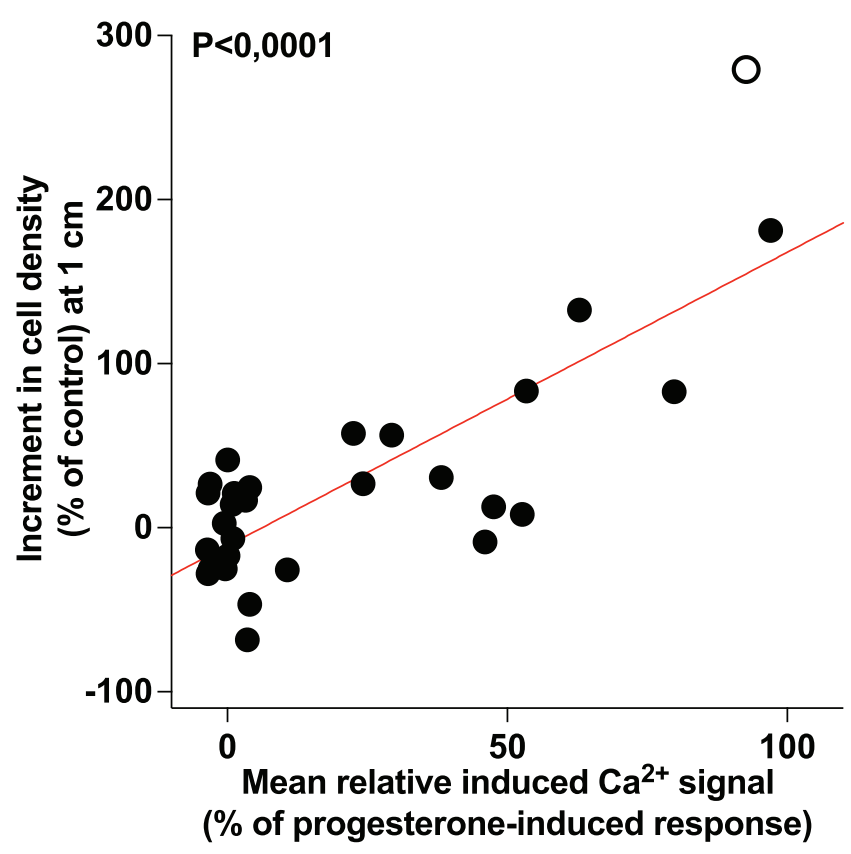

Figure 4

Scatter plot showing the ability of the chemical UV filter to induce a rise in $\left[\mathrm{Ca}^{2+}\right]_{\mathrm{i}}$ at $10 \mu \mathrm{M}$ (in \% of the paired progesterone-induced response $(5 \mu \mathrm{M}))($ mean \pm S.D.) $(21)$ on the $x$-axis and the increment in cell density at $1 \mathrm{~cm}$ into a viscous medium (in \% of negative control) (mean \pm S.D.) on the $y$-axis. The white dot indicates the UV filter 3-BC, which induced a significant increment in cell density at $1 \mathrm{~cm}$ into a viscous medium. The line is obtained by linear regression and the $P$ value for the association is obtained from the two-way ANOVA. 
Figure 5

Nonviable cells (\%) after $20 \mathrm{~h}$ of incubation with $0.1 \%$ DMSO (negative control) and UV filters at $10 \mu \mathrm{M}$ (mean \pm s.D.). The UV filters are ordered on the $x$-axis according to their ability to induce a rise in $\left[\mathrm{Ca}^{2+}\right]_{\mathrm{i}}$, (decreasing from left to right). The UV filters left to the vertical line induce a rise in $\left[\mathrm{Ca}^{2+}\right]_{i}$ at $10 \mu \mathrm{M}$, whereas those right of the vertical line do not induce a rise in $\left[\mathrm{Ca}^{2+}\right]_{i}$ at $10 \mu \mathrm{M}(21) .{ }^{* *}$ Adjusted $P$-value $\leq 0.01$. impair fertility by inducing premature acrosome reaction in human sperm cells.

In support of our findings, $\mathrm{p}, \mathrm{p}^{\prime}$-DDE has been shown to induce a rise in $\left[\mathrm{Ca}^{2+}\right]_{\mathrm{i}}$ via CatSper and acrosome reaction (18). Similarly, in our previous study (17), we showed that the chemical UV filters 4-MBC and 3-BC could induce a rise in $\left[\mathrm{Ca}^{2+}\right]_{i}$ via CatSper and acrosome reaction. Our results here confirmed these findings for 4-MBC and 3-BC. Also, triclosan has been shown to induce a CatSper-independent rise in $\left[\mathrm{Ca}^{2+}\right]_{\mathrm{i}}$ and acrosome reaction (17).

In contrast to our findings, diethylstilbestrol (DES) was found neither to induce acrosome reaction nor increase sperm penetration, even though it was found to induce a $\mathrm{Ca}^{2+}$ influx via CatSper (20). Methodological differences might account for these contradicting findings. Unlike in our study, Zou et al. added DES to non-capacitated sperm cells and allowed the sperm cells to incubate with DES for $4 \mathrm{~h}$ before assessing acrosome reaction or sperm penetration. In our study, we on the other hand added the chemical UV filters to already capacitated sperm cells $30 \mathrm{~min}$ before assessing acrosome reaction and to non-capacitated sperm cells just prior to assessing sperm penetration.

Interestingly, however, DES was found to dosedependently inhibit both the progesterone-induced rise in $\left[\mathrm{Ca}^{2+}\right]_{\mathrm{i}}$, acrosome reaction and sperm penetration (20). We have previously shown that the UV filters 4-MBC (17), 3-BC and BCSA (21) can competitively inhibit the progesterone-induced rise in $\left[\mathrm{Ca}^{2+}\right]_{i}$, indicating that these UV filters might similarly be able to inhibit the progesterone-induced acrosome reaction and sperm penetration.

$$
\text { http://www.endocrineconnections.org }
$$

Progesterone is a weak inducer of hyperactivation, inducing only a small increment in the proportion of hyperactivated cells $(13,14)$, with no relationship between the induced rise in $\left[\mathrm{Ca}^{2+}\right]_{\mathrm{i}}$ and hyperactivation response (13). In our study, neither progesterone, nor the chemical UV filters, induced hyperactivation. In our previous study (17), 4-MBC was shown to lower the frequency and enhance the asymmetry of the flagellar beat in a single sperm cell, indicating that 4-MBC could induce hyperactivation. With the experimental setup in our study we could, however, not find an increase in hyperactivation after treatment with 4 -MBC on a sperm cell population. Studies have shown that only a given proportion of sperm cells in a population respond to treatment with a $\mathrm{Ca}^{2+}$ signal-inducing $\operatorname{EDC}(18,21)$, probably due to the heterogeneity of sperm samples (42). These findings could explain how hyperactivation can be induced in individual sperm cells, while the proportion of hyperactivated cells in the whole sperm population remains relatively stable.

Most UV filters tested did not affect viability, similar to DES (20) and p,p'-DDE upon one day of incubation (18). Taken together, our data are consistent with the notion that the induced rise in $\left[\mathrm{Ca}^{2+}\right]_{\mathrm{i}}$ in human sperm cells on itself does not affect sperm viability, and that the adverse effect of Avobenzone on viability is most likely independent from its effect on $\left[\mathrm{Ca}^{2+}\right]_{i}$.

Multiple EDCs have been shown to induce a rise in $\left[\mathrm{Ca}^{2+}\right]_{i}$ in human sperm cells through interaction with CatSper $(17,18,19,20,21)$, as have multiple pharmacological ligands (43). Our findings for the chemical UV filters tested here indicate that other compounds that activate CatSper could similarly affect

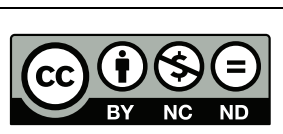

This work is licensed under a Creative Commons Attribution-NonCommercial-NoDerivatives 4.0 International License. 
sperm function in a progesterone-like manner. EDCs have been shown to act additively to induce a rise in $\left[\mathrm{Ca}^{2+}\right]_{\mathrm{i}}$ in human sperm cells $(17,21)$, suggesting that these EDCs could similarly act additively to induce acrosome reaction and increase sperm penetration.

In conclusion, several chemical UV filters known to mimic the effect of progesterone on $\mathrm{Ca}^{2+}$ signaling in human sperm cells were shown to induce acrosome reaction and sperm penetration in a progesterone-like manner. Exposure to these chemical UV filters could impair fertility by interfering with sperm function, e.g. through induction of premature acrosome reaction. Further studies are needed to confirm our results in vivo.

\section{Supplementary data}

This is linked to the online version of the paper at https://doi.org/10.1530/ EC-17-0156.

\section{Declaration of interest}

The authors declare there is no conflict of interest that could be perceived as prejudicing the impartiality of the research reported.

\section{Funding}

This study was supported by a PhD Internship Scholarship from the Faculty of Health and Medical Sciences, University of Copenhagen, an EDMaRC research grant from the Kirsten and Freddy Johansen's Foundation, and the Innovation Fund Denmark (InnovationsFonden, grant number 142013-4).

\section{Author contribution statement}

Study design: A R, N E S; execution: A R, D L E; analysis: A R, J H P; manuscript drafting: $A R, S D, N E S$ and critical discussion: $A R, D L E, K A$, J H P, S D, NES.

\section{Acknowledgments}

The author would like to thank Ina Lund for her technical assistance with the semen donor corps and the swim-up preparation of the semen samples, as well as for her help with the sperm penetration tests and CASA experiments.

\section{References}

1 Skakkebaek NE, Rajpert-De Meyts E, Buck Louis GM, Toppari J, Andersson A-M, Eisenberg ML, Jensen TK, Jørgensen N, Swan SH, Sapra KJ, et al. Male reproductive disorders and fertility trends: influences of environment and genetic susceptibility. Physiological Reviews 201696 55-97. (https://doi.org/10.1152/ physrev.00017.2015)

2 Diamanti-Kandarakis E, Bourguignon J-P, Giudice LC, Hauser R, Prins GS, Soto AM Zoeller RT \& Gore AC. Endocrine-disrupting chemicals: an Endocrine Society scientific statement. Endocrine Reviews 200930 293-342. (https://doi.org/10.1210/er.2009-0002)

http://www.endocrineconnections.org https://doi.org/10.1530/EC-17-0156 (c) 2018 The authors Published by Bioscientifica Ltd
3 Bergman A, Heindel JJ, Kasten T, Kidd KA, Jobling S, Neira M, Zoeller RT, Becher G, Bjerregaard P, Bornman R, et al. The impact of endocrine disruption: a consensus statement on the state of the science. Environmental Health Perspectives 2013121 A104-A106. (https://doi.org/10.1289/ehp.1205448)

4 Hull MG, Glazener CM, Kelly NJ, Conway DI, Foster PA, Hinton RA Coulson C, Lambert PA, Watt EM \& Desai KM. Population study of causes, treatment, and outcome of infertility. BMJ 1985291 1693-1697. (https://doi.org/10.1136/bmj.291.6510.1693)

5 Jain T \& Gupta RS. Trends in the use of intracytoplasmic sperm injection in the United States. New England Journal of Medicine 2007 357 251-257. (https://doi.org/10.1056/NEJMsa070707)

6 Kupka MS, Ferraretti AP, de Mouzon J, Erb K, D’Hooghe T, Castilla JA, Calhaz-Jorge C, De Geyter C, Goossens V \& European IVF-Monitoring Consortium, for the European Society of Human Reproduction and Embryology. Assisted reproductive technology in Europe, 2010: results generated from European registers by ESHRE. Human Reproduction 201429 2099-2113. (https://doi.org/10.1093/ humrep/deu175)

7 Publicover S, Harper CV \& Barratt C. $\left[\mathrm{Ca}^{2+}\right]_{\mathrm{i}}$ signalling in spermmaking the most of what you've got. Nature Cell Biology 20079 235-242. (https://doi.org/10.1038/ncb0307-235)

8 Publicover SJ, Giojalas LC, Teves ME, de Oliveira GSMM, Garcia AAM, Barratt CLR \& Harper CV. $\mathrm{Ca}^{2+}$ signalling in the control of motility and guidance in mammalian sperm. Frontiers in Bioscience 200813 5623-5637. (https://doi.org/10.2741/3105)

9 Lishko PV, Kirichok Y, Ren D, Navarro B, Chung J-J \& Clapham DE. The control of male fertility by spermatozoan ion channels. Annual Review of Physiology 201274 453-475. (https://doi.org/10.1146/ annurev-physiol-020911-153258)

10 Strünker T, Goodwin N, Brenker C, Kashikar ND, Weyand I, Seifert R \& Kaupp UB. The CatSper channel mediates progesterone-induced $\mathrm{Ca}^{2+}$ influx in human sperm. Nature 2011471 382-386. (https://doi. org/10.1038/nature09769)

11 Lishko PV, Botchkina IL \& Kirichok Y. Progesterone activates the principal $\mathrm{Ca}^{2+}$ channel of human sperm. Nature $2011471387-391$. (https://doi.org/10.1038/nature09767)

12 Eisenbach M \& Giojalas LC. Sperm guidance in mammals - an unpaved road to the egg. Nature Reviews Molecular Cell Biology 20067 276-285. (https://doi.org/10.1038/nrm1893)

13 Alasmari W, Barratt CLR, Publicover SJ, Whalley KM, Foster E, Kay V, Martins da Silva S \& Oxenham SK. The clinical significance of calcium-signalling pathways mediating human sperm hyperactivation. Human Reproduction 201328 866-876. (https://doi. org/10.1093/humrep/des467)

14 Alasmari W, Costello S, Correia J, Oxenham SK, Morris J, Fernandes L, Ramalho-Santos J, Kirkman-Brown J, Michelangeli F, Publicover S, et al. $\mathrm{Ca}^{2+}$ signals generated by CatSper and $\mathrm{Ca}^{2+}$ stores regulate different behaviors in human sperm. Journal of Biological Chemistry 2013288 6248-6258. (https://doi.org/10.1074/jbc.M112.439356)

15 Tamburrino L, Marchiani S, Minetti F, Forti G, Muratori M \& Baldi E. The CatSper calcium channel in human sperm: relation with motility and involvement in progesterone-induced acrosome reaction. Human Reproduction 201429 418-428. (https://doi.org/10.1093/humrep/ $\operatorname{det} 454)$

16 Brenker C, Goodwin N, Weyand I, Kashikar ND, Naruse M, Krähling M, Müller A, Kaupp UB \& Strünker T. The CatSper channel: a polymodal chemosensor in human sperm. EMBO Journal 201231 1654-1665. (https://doi.org/10.1038/emboj.2012.30)

17 Schiffer C, Müller A, Egeberg DL, Alvarez L, Brenker C, Rehfeld A, Frederiksen H, Wäschle B, Kaupp UB, Balbach M, et al. Direct action of endocrine disrupting chemicals on human sperm. EMBO Reports 201415 758-765. (https://doi.org/10.15252/embr.201438869)

18 Tavares RS, Mansell S, Barratt CLR, Wilson SM, Publicover SJ \& Ramalho-Santos J. p, $\mathrm{p}^{\prime}$-DDE activates CatSper and compromises 
human sperm function at environmentally relevant concentrations. Human Reproduction 201328 3167-3177. (https://doi.org/10.1093/ humrep/det372)

19 Shannon M, Rehfeld A, Frizzell C, Livingstone C, McGonagle C, Skakkebaek NE, Wielogórska E \& Connolly L. In vitro bioassay investigations of the endocrine disrupting potential of steviol glycosides and their metabolite steviol, components of the natural sweetener Stevia. Molecular and Cellular Endocrinology 2016427 65-72. (https://doi.org/10.1016/j.mce.2016.03.005)

20 Zou Q-X, Peng Z, Zhao Q, Chen H-Y, Cheng Y-M, Liu Q, He YQ, Weng SQ, Wang HF, Wang T, et al. Diethylstilbestrol activates CatSper and disturbs progesterone actions in human spermatozoa. Human Reproduction 201732 290-298. (https://doi.org/10.1093/humrep/ dew332)

21 Rehfeld A, Dissing S \& Skakkebæk NE. Chemical UV filters mimic the effect of progesterone on $\mathrm{Ca}(2+)$ signaling in human sperm cells. Endocrinology 2016157 4297-4308. (https://doi.org/10.1210/ en.2016-1473)

22 Egeberg DL, Kjaerulff S, Hansen C, Petersen JH, Glensbjerg M, Skakkebaek NE, Jørgensen N \& Almstrup K. Image cytometer method for automated assessment of human spermatozoa concentration. Andrology 20131 615-623. (https://doi.org/10.1111/j.20472927.2013.00082.x)

23 Egeberg Palme DL, Johannsen TH, Petersen JH, Skakkebæk NE, Juul A, Jørgensen N \& Almstrup K. Validation of image cytometry for sperm concentration measurement: comparison with manual counting of 4010 human semen samples. Clinica Chimica Acta 2017 468 114-119. (https://doi.org/10.1016/j.cca.2017.02.014)

24 ESHRE Andrology Special Interest group. Guidelines on the application of CASA technology in the analysis of spermatozoa. ESHRE Andrology Special Interest Group. European Society for Human Reproduction and Embryology. Human Reproduction 199813 142-145.

25 Sánchez-Cárdenas C, Servín-Vences MR, José O, Treviño CL, Hernández-Cruz A \& Darszon A. Acrosome reaction and $\mathrm{Ca}^{2+}$ imaging in single human spermatozoa: new regulatory roles of $\left[\mathrm{Ca}^{2+}\right]_{\mathrm{i}}$. Biology of Reproduction 201491 67. (https://doi.org/10.1095/ biolreprod.114.119768)

26 Zoppino FCM, Halón ND, Bustos MA, Pavarotti MA \& Mayorga LS. Recording and sorting live human sperm undergoing acrosome reaction. Fertility and Sterility 201297 1309-1315. (https://doi. org/10.1016/j.fertnstert.2012.03.002)

27 Mortimer ST, Swan MA \& Mortimer D. Effect of seminal plasma on capacitation and hyperactivation in human spermatozoa. Human Reproduction 199813 2139-2146. (https://doi.org/10.1093/ humrep/13.8.2139)

28 Krausz C, Bonaccorsi L, Luconi M, Fuzzi B, Criscuoli L, Pellegrini S, Forti G \& Baldi E. Intracellular calcium increase and acrosome reaction in response to progesterone in human spermatozoa are correlated with in-vitro fertilization. Human Reproduction $1995 \mathbf{1 0}$ 120-124. (https://doi.org/10.1093/humrep/10.1.120)

29 Oehninger S, Blackmore P, Morshedi M, Sueldo C, Acosta AA \& Alexander NJ. Defective calcium influx and acrosome reaction (spontaneous and progesterone-induced) in spermatozoa of infertile men with severe teratozoospermia. Fertility and Sterility $19946 \mathbf{6 1}$ 349-354. (https://doi.org/10.1016/S0015-0282(16)56530-3)
30 Falsetti C, Baldi E, Krausz C, Casano R, Failli P \& Forti G. Decreased responsiveness to progesterone of spermatozoa in oligozoospermic patients. Journal of Andrology 199314 17-22.

31 Krausz C, Bonaccorsi L, Maggio P, Luconi M, Criscuoli L, Fuzzi B, Pellegrini S, Forti G \& Baldi E. Two functional assays of sperm responsiveness to progesterone and their predictive values in in-vitro fertilization. Human Reproduction 199611 1661-1667. (https://doi. org/10.1093/oxfordjournals.humrep.a019466)

32 Guidobaldi HA, Hirohashi N, Cubilla M, Buffone MG \& Giojalas LC. An intact acrosome is required for the chemotactic response to progesterone in mouse spermatozoa. Molecular Reproduction and Development 201784 310-315. (https://doi.org/10.1002/ mrd.22782)

33 Liu DY, Garrett C \& Baker HWG. Acrosome-reacted human sperm in insemination medium do not bind to the zona pellucida of human oocytes. International Journal of Andrology 200629 475-481. (https://doi.org/10.1111/j.1365-2605.2006.00681.x)

34 Inoue N, Satouh Y, Ikawa M, Okabe M \& Yanagimachi R. Acrosomereacted mouse spermatozoa recovered from the perivitelline space can fertilize other eggs. PNAS 2011108 20008-20011. (https://doi. org/10.1073/pnas.1116965108)

35 Jin M, Fujiwara E, Kakiuchi Y, Okabe M, Satouh Y, Baba SA, Chiba K \& Hirohashi N. Most fertilizing mouse spermatozoa begin their acrosome reaction before contact with the zona pellucida during in vitro fertilization. PNAS 2011108 4892-4896. (https://doi. org/10.1073/pnas.1018202108)

36 Liu DY \& Baker HW. Inhibition of acrosin activity with a trypsin inhibitor blocks human sperm penetration of the zona pellucida. Biology of Reproduction 199348 340-348. (https://doi.org/10.1095/ biolreprod48.2.340)

37 Wassarman PM, Jovine L \& Litscher ES. A profile of fertilization in mammals. Nature Cell Biology 20013 E59-E64. (https://doi. org/10.1038/35055178)

38 Fénichel P, Donzeau M, Farahifar D, Basteris B, Ayraud N \& Hsi BL. Dynamics of human sperm acrosome reaction: relation with in vitro fertilization. Fertility and Sterility 199155 994-999.

39 Liu DY \& Baker HW. Tests of human sperm function and fertilization in vitro. Fertility and Sterility 199258 465-483. (https://doi. org/10.1016/S0015-0282(16)55247-9)

40 Takahashi K, Wetzels AM, Goverde HJ, Bastaans BA, Janssen HJ $\&$ Rolland R. The kinetics of the acrosome reaction of human spermatozoa and its correlation with in vitro fertilization. Fertility and Sterility 199257 889-894. (https://doi.org/10.1016/S00150282(16)54976-0)

41 Cummins JM, Pember SM, Jequier AM, Yovich JL \& Hartmann PE. A test of the human sperm acrosome reaction following ionophore challenge. Relationship to fertility and other seminal parameters.. Journal of Andrology 199112 98-103.

42 Okabe M. The cell biology of mammalian fertilization. Development 2013140 4471-4479. (https://doi.org/10.1242/dev.090613)

43 Martins da Silva SJ, Brown SG, Sutton K, King LV, Ruso H, Gray DW, Wyatt PG, Kelly MC, Barratt CLR \& Hope AG. Drug discovery for male subfertility using high-throughput screening: a new approach to an unsolved problem. Human Reproduction 201716 1-11. (https://doi.org/10.1093/humrep/dex055)

Received in final form 22 August 2017

Accepted 5 September 2017

Accepted Preprint published online 5 September 2017 http://www.endocrineconnections.org https://doi.org/10.1530/EC-17-0156
(C) 2018 The authors
Published by Bioscientifica Ltd

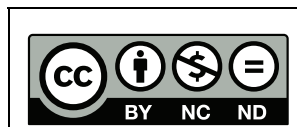

This work is licensed under a Creative Commons Attribution-NonCommercial-NoDerivatives 4.0 International License. 